\title{
Erratum to: Microcephalic Osteodysplastic Primordial Dwarfism, Type II: a Clinical Review
}

\author{
Michael B. Bober ${ }^{1,2}$ - Andrew P. Jackson ${ }^{3}$
}

Published online: 15 July 2017

(C) The Author(s) 2017. This article is an open access publication

\section{Erratum to: Curr Osteoporos Rep (2017) 15(2):61-69 DOI 10.1007/s11914-017-0348-1}

The article Microcephalic Osteodysplastic Primordial Dwarfism, Type II: a Clinical Review, written by Michael B. Bober and Andrew P. Jackson, was originally published Online First without open access. After publication in volume 15, issue 2, page 61-69 the author decided to opt for Open Choice and to make the article an open access publication. Therefore, the copyright of the article has been changed to (C) The Author(s) 2017 and the article is forthwith distributed under the terms of the Creative Commons Attribution 4.0
International License (http://creativecommons.org/licenses/ by/4.0/), which permits use, duplication, adaptation, distribution and reproduction in any medium or format, as long as you give appropriate credit to the original author(s) and the source, provide a link to the Creative Commons license, and indicate if changes were made.

Open Access This article is distributed under the terms of the Creative Commons Attribution 4.0 International License (http:// creativecommons.org/licenses/by/4.0/), which permits unrestricted use, distribution, and reproduction in any medium, provided you give appropriate credit to the original author(s) and the source, provide a link to the Creative Commons license, and indicate if changes were made.

The online version of the original article can be found at http://dx.doi.org/ 10.1007/s11914-017-0348-1

Michael B. Bober

Michael.Bober@nemours.org

Andrew P. Jackson

Andrew.jackson@igmm.ed.ac.uk

1 Stanley Kimmel Medical College, Thomas Jefferson University, Philadelphia, PA, USA

2 A. I. DuPont Hospital for Children, 1600 Rockland-Road, Wilmington, DE 19803, USA

3 MRC Human Genetics Unit, Institute of Genetics and Molecular Medicine, University of Edinburgh, Edinburgh EH4 2XU, UK 